\title{
Digitization of industrial work: development paths and prospects
}

\author{
Hartmut Hirsch-Kreinsen ${ }^{1}$
}

Published online: 23 March 2016

(C) The Author(s) 2016. This article is published with open access at Springerlink.com

\begin{abstract}
This paper summarizes considerations and preliminary research results on the consequences of the progressive use of digital technologies in industrial work. The focus is particularly on the situation in German industry, where this development has been intensively discussed as "Industry 4.0". Starting point is the assumption that currently a far-reaching technology push in industrial production can be observed. In terms of the potential consequences for industrial labor foreseen by the literature, currently contradictory development scenarios are being discussed. For one thing, the volume of potential job losses caused by the new technologies is highly controversial. For another, diverging consequences for job activities and qualifications can be recognized, interpreted as the "upgrading", respectively "polarization" of skills. What concrete changes actually occur however, is dependent on the influence of numerous factors. Especially, what concept of technology automation is realized in each case, and its respective implementation process, is significant here. The conclusion reached is that, in the medium term, at the most a somewhat limited spread of digital technologies and their consequences can be expected to occur.
\end{abstract}

Keywords Digitization of work · Industry 4.0 - Industrial work $\cdot$ Development of skills and qualifications

Hartmut Hirsch-Kreinsen

hartmut.hirsch-kreinsen@tu-dortmund.de

1 Faculty of Economics and Social Sciences, Economic and Industrial Sociology, TU Dortmund University, Otto-Hahn-Str. 4, 44227 Dortmund, Germany

\section{Digitalisierung industrieller Arbeit: Entwicklungspfade und Perspektiven}

Zusammenfassung Im Beitrag werden erste Forschungsergebnisse über die Konsequenzen des Einsatzes digitaler Technologien für industrielle Arbeit zusammengefasst. Der Fokus richtet sich besonders auf die Entwicklung der deutschen Industrie, deren Entwicklung unter dem Label „Industrie 4.0“ seit längerem intensiv diskutiert wird. Ausgangsannahme ist, dass gegenwärtig ein weit reichender Technologieschub in der industriellen Produktion stattfindet. In Hinblick auf die Konsequenzen für Arbeit können auf der Basis der derzeit vorliegenden Literatur und der Forschungsergebnisse allerdings nur widersprüchliche Annahmen formuliert werden. Dies betrifft erstens die Frage nach den erwartbaren Arbeitsplatzverlusten. Zweitens muss die absehbare Entwicklung von Tätigkeiten und Qualifikationen kontrovers diskutiert werden. Auf der einen Seite finden sich Tendenzen des „Upgrading“, auf der anderen der „Polarisierung“ von Qualifikationen. Welcher Entwicklungspfad sich letztlich durchsetzt ist abhängig von einer Reihe von Bedingungen wie etwa das jeweils verfolgte Technologiekonzept und dem Verlauf des Einführungsprozesses der neuen Technologien. Insgesamt allerdings ist nur eine begrenzte Verbreitung der neuen digitalen Technologien zu erwarten.

\section{Technology push towards digitization}

The following paper deals with the question of what the consequences are of the diffusion and implementation of digital technologies for work, and in particular, for work in industries. The widespread thesis is that this technology is opening completely new and unknown technology applica- 
tion potentials with no less than disruptive social and economic consequences (Avant 2014). In this view, a new era is recognizable that in the international debate is variously called the "second machine age" (Brynjolfsson and McAfee 2014), the "third industrial revolution" (Rifkin 2011) or, in the German-speaking world, the "fourth industrial revolution"-respectively, "Industry 4.0" (research Union and acatech 2013). Without question, this debate has all the characteristics of "hype": spectacular changes and prospects are predicted and, in professional circles, politics and far beyond, no other issue is so often attributed such an important role in the visions of future social and economic development. One is reminded of the second half of the 1990s as the New Economy's "multimedia", "World Wide Web" and "e-commerce" seemed to hail the advent of a new societal prosperity. Therefore some observers of the current development wonder whether the current debate is perhaps just "new wine" being poured into "old bottles" (e.g. Jasperneite 2012).

In summing up this debate however, beyond all the rhetorical exaggerations there are some quite convincing arguments for the reality of an advance in technological development that is now taking place, the structural consequences of which are still hardly foreseeable. The assumption is that the development of digital technologies has reached a stage that is opening up entirely new qualities of application that are not structurally comparable to those of previous decades. To ground this claim of a new quality of technological development with considerably widened application potentials and structure-changing consequences, the literature invokes almost unanimously what has been a virtual leap in the technological progress of recent years (for different perspectives see e.g. Geisberger and Broy 2012; Avant 2014; Brynjolfsson and McAffee 2014, p. 4; Evangelista et al. 2014). This development, for the majority of authors, has brought an extremely ambivalent social change: the one hand, very beneficial consequences particularly for income and potential for consumption. On the other hand digitization also brings some very thorny challenges in terms of accompanying changes to economic structures and work.

In the following therefore, digitization refers to the process of socioeconomic change triggered by the introduction of digital technology, the application systems based on it, and especially, their production networks (Hess 2015). Here two phases of digitization can be distinguished: In the first phase, this process has already been established since at least the end of the 1990s in those sectors of the economy where the production, consumption and communication is directly based on intangible transactions and the use of data and information. These are above all service sectors such as music production and distribution, publishing and press, or also financial services, the digitization of which has meant far-reaching structural changes in individual business models as well as company and industry branch structures (Zuboff 2010; Brynjolfsson and McAfee 2014). Amazon is often cited as an example of cases where it makes less and less sense to ask whether a company is a retailer, logistics company, web-based service company or-as one might think more recently - perhaps also a grocer. For this company like many similar ones, it is rather only the systematic use of "big data" that is the basis of its business model.

Today however, already a second phase of the process aims to realize the digitization of physical objects of all kinds. Shoshana Zuboff calls this development a "second-wave mutation" of the technological and related socioeconomic change (Zuboff 2010, p. 8). In a primarily technological perspective this context is also called the "Internet of things" (e.g. Fleisch and Mattern 2005; Bullinger and ten Hompel 2007). Here are spoken of "cyber-physical systems" (CPS) which open huge and previously unknown potential for many different application areas such as housing, medical, or transportation systems, in addition to general industrial production (e.g. Geisberger and Broy 2012). By the term CPS is understood the information technology interaction between, on the one hand, physical systems with embedded software, and, on the other hand, global data networks with distributed and interactive application systems. More concretely, CPS means "smart" and "intelligent" devices, vehicles and equipment, as well as the logistics, coordination and management processes that are linked to advanced Internet applications. The hypothesis has therefore also been formulated that digitization is now on the point of encroaching on the core areas of economic activity and thus of creating a hitherto unknown connectedness between completely new application areas and their societal consequences. The materiality of the processes in question however makes this new digitization wave far more complex than the previous one (e.g. Zuboff 2010; Geisberger and Broy 2012).

A main thematic point of the current debate is the digitization of industrial production and logistics, respectively the industrial application of CPS technologies which has been propagated since 2011 especially in Germany by computer and engineering researchers, influential business associations, technology-intensive companies in the electrical and mechanical engineering industries, as well as policymakers under the catchy label "Industry 4.0" (research Union and acatech 2013). On the one hand this connects to long-discussed and partially realized production concepts based on a progressive integrated use of databases for planning, managing and monitoring of production (e.g. Westkämper et al. 2007). Prominent among these was already in the 1980s the concept "Computer Integrated Manufacturing" (CIM) (Harrington 1973; Scheer 1987; Hirsch-Kreinsen et al. 1990). 
On the other hand it is stressed that Industry 4.0, compared to the previous approaches, is aiming for a completely new level of process automation. Through highly flexible Internet linkage of data levels with real factory processes, fundamentally new potentials for the planning, control and the organization of production processes and entire value chains are being opened. In addition, it is emphasized that the advanced use of customer and market data now possible is a prerequisite to the development of entirely new business models and the acquisition of new market segments (e.g. Broy 2010; Reinhart et al. 2013; Sendler 2013). Overall therefore, all the authors therefore assume that with the realization and diffusion of Industry 4.0 systems, as well as generally with the increasing digitization of social and economic processes, conversion processes will be triggered that in the longer term are sustainable but not yet foreseeable in their consequences for socioeconomic structures and particularly, for labor (e.g. Hirsch-Kreinsen et al. 2015).

\section{Research question and methodological basis}

The following argument takes up the question of possible changes to industrial work particularly, tying it in with the previous, very much IT-related issues. Concretely, two themes are taken up that are central to the current debate over the digitization of industrial work: Firstly, the question of possible quantitative effects on employment, and secondly, that of the structural transformation of the job activities themselves and the skills sets that will be needed to perform them. The analysis presumes a broad understanding of industrial work for a sufficient grasp of the import of this transformation process. Basically the concept includes all the directly and indirectly value-creating activities that occur in industrial operations, from the operative and executive levels of the work organization, to the strategic levels of planning, regulation and monitoring, to the areas of lower and mid-level management of production processes, as well as to the activities of technical experts.

the following argumentation is highly explorative in character and based on a review and systematic résumé of the available literature in the area of social science-oriented industrial and labor research that concerns itself more or less explicitly with the introduction of new technologies, e.g. studies in the sub-disciplines industrial engineering, psychology of work, sociology of work and social science research on innovation. In particular however, the results will be used of those few social science studies that have dealt in recent years with issues of the diffusion of information technologies and their impact on labor. Specifically, these are several studies in the psychology of work and a few, especially more recent, reports from the sociology of work and industrial sociology. ${ }^{1}$ And finally, the analysis is based on information and production technology studies that deal more or less directly with the question of the consequences of digitization for work. Because of the particularly intensive discussion in Germany over the perspectives on Industry 4.0, these resources are most often original German-language studies. Overall, the studies are directed at both social and macro-structural changes in the labor landscape, as well as possible conversion processes at the micro-level of individual companies and workplaces. As far as possible in the further argumentation these different levels will be taken up analytically in complement to each other.

\section{Developmental perspectives on industrial work}

Summarizing current research results on IT-related change in industrial work, a partly very divergent picture emerges, ultimately in order to justify the very different development perspectives on work. On the one hand this deals with the nationally and internationally much-discussed theses on the question of the quantitative employment effects of digitization, and on the other, the question of the qualitative, i.e. structural consequences for jobs and skills.

\subsection{Controversial employment effects}

\subsubsection{Long-term compensation for initial job losses}

Concerning possible job losses caused by digitization research refers basically to the well-known debate about technological unemployment. As John Maynard Keynes put it the increase of technical efficiency takes place faster than we can deal with the problem of labor absorption (Keynes 1963). In regard to this question, there is the often-cited "conventional wisdom" of labor-market research going back to Ricardo, according to which short-term negative employment effects of technological change are always compensated for in the longer term by efficiency gains, new products, new markets and new employment opportunities (e.g. Agion and Howitt 1994). Thus Evangelista et al. (2014) see, on the basis of a detailed literature review in anticipation of the adoption of digital technologies, little clear impact on employment. In particular, they emphasize that it is particularly difficult to attribute causal effects on employment to this technology. The reason for this lies in their potentially widespread use in many areas. Although substantial empirical studies are lacking, in the literature pre-

\footnotetext{
${ }^{1}$ To be mentioned here are for example: Spath et al. 2013; Hirsch-Kreinsen 2014; Botthof and Hartmann 2015; Kersten et al. 2014; HirschKreinsen et al. 2015.
} 
dominates an optimistic view of the long-term employment effects of digital technologies. This is because one must see both the directly negative and the indirectly positive effects on employment as a result of efficiency improvements and price reductions, and the opening up of new markets (Evangelista et al. 2014, p. 806).

A similarly positive view of the impact on employment can be found in the context of Germany's 4.0 debate. Here are predicted not only generally high productivity gains and economic growth rates (e.g. Bauer et al. 2015), but with that also consistently positive employment effects. Thus, on the results of the study by Spath et al. (2013, pp. 46) the vast majority of industrial enterprises assume that human labor will remain significant in industrial production in the next few years and not be reduced. The same is found in a study by the Boston Consulting Group: "In our analysis of Industry 4.0's impact on German manufacturing, we found that the growth it stimulates will lead to a $6 \%$ increase in employment during the next 10 years.... And demand for employees in the mechanical engineering sector may rise even more - by as much as $10 \%$ during the same period" (BCG 2015, p. 8). Following this study, job growth in German manufacturing between 2015 and 2025 will amount numerically to about 390,000 jobs.

\subsubsection{Sweeping job losses}

In contrast, other authors argue that this employment compensation mechanism is no longer at work in the labor market in conditions of today's diffusion of digital technologies, as it was in the past. Thus Brynjolfsson and McAfee (2014, p. 177 ff.) emphasize that the increasingly rapid development and diffusion of digital technologies implies an increasingly widening gap between the new demands of technology and the generally more slowly effective socioeconomic adaptation mechanisms and the implicated opportunities for employees and institutions. The authors speak of an "...inability of our skills, organizations, and institutions to keep pace with technical change" (ibid.: 178). In addition, however, also the volume of available jobs for job seekers is dwindling increasingly, since the demand for many tasks and qualifications is dropping. Many jobs are being replaced by digitization, creating increasing job losses in those areas. The authors see their assumptions confirmed by the rising labor productivity and falling employment figures from the first half of the last decade (ibid.: 165).

Frey and Osborne reinforce this view with an analysis of the US labor market, which shows that very significant potentials for job losses go hand in hand with digital technologies. With regard to recent advances in "machine learning" and "mobile robotics", the authors have developed a methodology to categorise occupations according to their susceptibility to computerization. This methodology is used to assess the probability of computerisation for 702 occupations, and the impacts of computerisation on US labour market outcomes. The authors differentiate between high, medium and low risk occupations, depending on their probability of computerisation. Their argument is that not only simple, but in particular routinizable tasks including more complex activities can be automated by the new technologies. Therefore, they conclude that almost half of all current jobs from the most various economic sectors could be substituted in this way. Their central message is that approximately $47 \%$ of all activities on the American labor market over the next one or two decades are potentially threatened by automation (Frey and Osborne 2013, pp. 38.). Frey and Osborne speak of two different waves of far-reaching effects of computer applications on employment in the next few decades: the first wave comprises a pattern of progressive automation, namely the substitution of primarily routinizable and at least partially non-routinized activities by digitized technologies in the most various sectors. They expect a second wave of automation to follow, which will spread to activities comprising creative and socially interactive tasks. Their expectation is that, in contrast, “...most management, business, and finance occupations, which are intensive in generalist tasks requiring social intelligence, will be largely confined to the low-risk category. The same is true of most occupations in education, healthcare, as well as arts and media jobs." (Frey and Osborne 2013, p. 40)

On the basis of the same concept analysis Bowles (2014) calculates similarly high job substitution risks for the European labor market. He differentiates between different country groups in Europe. With regard to the German labor market he concludes that more than $51 \%$ of all activities were at risk of being replaced in the long term by automated processes through digitization. The reason for this high percentage is the importance of industrial work that may be threatened in the near future by especially rapid digitization spurts. A study by INGDI Bank on the prospects for the German labor market comes to yet farther-reaching assumptions (ING DiBa 2015). This study, oriented on the analysis concept of Frey and Osborne, "investigated approximately $81 \%$ of low-level" and marginally employed persons in Germany. On this basis the study arrives at the statement that about 18.3 million, or $59 \%$ of these jobs are at risk in their current form from the progressive technologizing of the German economy. The study indicates these are most often transport and storage activities, general auxiliary personnel, office and service-sector work. The authors of this study emphasize however at the same time that this is not expected to lead to abrupt job losses; rather, they expect a process of slow substitution or exchange, as new technologies, in particular easily deployable robots, come to dominate only gradually. The principle however is to assume a 
fundamental transformation of the labor market as a result of digitization and Industry 4.0.

\subsubsection{Relativizations}

It is not surprising that the outlined forecasts of far-reaching job losses through the application of digital technologies in the political and scientific debate are controversial to the extreme. Although some authors in the context of the "Industry 4.0" debate also assume that the employment volume in total could shrink, they reject the volumes of job losses mentioned. The critical arguments listed relate primarily to the fact that in these labor market forecasts it was purely a potential assessment of technological development and static analyses of occupations; ultimately, these are "automation probabilities" for existing occupations, without regard to the specific operating conditions involved. Above all however, some critics say studies such as those of Frey and Osborne (2014) neglect the peculiarities of the actual activities of the different occupational groups which, in an assessment of their activities substitutability, can lead to differentiated results. Thus, starting from these considerations Bonin et al. come to significantly lower predictions: the share of jobs with a high level of automation probability in the US is at just $9 \%$, while in Germany this is still only $12 \%$ (Bonin et al. 2015, pp. 14). In a recently published studies by Dengler and Matthes present similar findings for the German labor market on the base of a further developed methodology. They calculate the substitution potentials of occupations based on German occupational data from an expert data base of the Federal Employment Agency. Following their results $15 \%$ of employees have a high substitution potential in the year 2013 in Germany; these employees are employed in an occupation in which more than $70 \%$ of the tasks could be substituted by computers (Dengler and Matthes 2015). ${ }^{2}$

In the opinion of other critics, the assessments of possible job losses above all completely neglect the highly qualitative job skills required for working with complex technologies. Their argument is that because these are indispensable to the efficiency of digitized processes, they present an obstacle to far-reaching automation attempts. This is pointed out particularly by Sabine Pfeiffer and Anne Suphan (2015), who show on the basis of their "work capacity index" that the greater part of the workforce is able to deal with technology related complexity demands on the basis of available experiential resp. implicit knowledge, and that such workers are therefore crucial to coping with the challenge of digitization. They name here a share of $71 \%$ of all employed persons in Germany (ibid.: p. 222). The conclusion is that

\footnotetext{
${ }^{2}$ See also similar findings of a study based on scenario analysis about the economic consequences of "Industry 4.0" by Wolter et al. (2015).
}

this activity share is relatively stable and secure against the presumed far-reaching substitution effects. Beyond these concrete numerical data that relativize far-reaching effects, there are more fundamental arguments that put into question extensive substitution (see also part 4.1). It is pointed out that technological potentials are often overestimated, that both professional as well as activity structures have a longer-term high dynamic that works against linear automation effects, and finally, that macroeconomic adjustment processes, as also emphasized by the representatives of the compensation thesis (see above), are overlooked.

\subsection{Divergent development paths for jobs and qualifications}

The question of the structural change in job activities and qualifications as a result of digitization can also be scarcely given a definitive answer. To sum up the existing research results, a wide spectrum of different development paths of work can be assumed, which is delimited by two poles. These poles can be labelled the upgrading of qualifications and the polarization of qualifications. Summing up previous findings of social science labor research, these development perspectives of labor could also observed in earlier phases of mechanization of work processes (e.g. Altmann et al. 1992). However, it can be assumed that in the current phase of the digitization these trends get worse in a specific way.

\subsubsection{Upgrading of qualifications}

The one pole describes a development path by which the digitization of work generally brings an appreciation, or an "upgrading" of required worker qualifications. This development perspective is represented relatively strongly in both the scientific as well as public debate. Following the study by Zuboff (1988, pp. 10) on the consequences of the use of information technologies, an upgrading of qualifications is seen to take place in two ways:

On the one hand this is considered the result of progressive computer technology automation of simple jobs that are extensively substituted. The prerequisite for this is, that it be routinized and to a large extent highly rule-based work that therefore can be taken over relatively easily by computer algorithms. As aforementioned, Frey and Osborne (2013) speak in this context of waves of extensive substitution effects of computer use that are foreseeable for the coming years particularly in these activities. This upgrading model is referred to in the literature also as "skill-biased technical change" - i.e. the winners in the progressive substitution by digitized technologies are those groups of workers who already feature higher qualifications and more behavioral resources (see also Brynjolfsson and McAfee 2014, p. 136). 
On the other hand, upgrading can be understood as a process that captures all employee groups in general. Digitization of work in this perspective is a process of the computerization of work which makes increasingly available a wide variety of information about ongoing processes. Their complexity and possible uses result fundamentally in new and hitherto unknown requirements for all activities. Zuboff therefore speaks of the growing importance of "intellective skills" based above all on a theoretical understanding of processes, i.e. the ability to grasp the prerequisites and consequences of the use of data available at any time (Zuboff 1988, p. 94). The general consequence would be "better jobs - jobs that at every level would be enriched by an informating technology" (ibid.: 159). Zuboff describes this development perspective that information technology has the unique capacity to "informate" nearly all activities and jobs (ibid.: 10).

These tendencies towards qualification upgrading are reflected in the literature, especially for current information technology applications of the "Internet of things", because such systems provide, through their data acquisition and evaluation, a degree of transparency over production processes in a previously unknown way (Zammuto et al. 2007; Evangelista et al. 2014; Boos et al. 2013). Thus also in the public and innovation policy debate over Industry 4.0, it is also emphasized that in future, a general upgrading of qualifications will be possible and also certainly will occur. Here reference may be made to Henning Kagermann as representative of a great variety of authors and positions, and one of the leading advocates of Industry 4.0 in Germany, in whose opinion people in the future will be employed less as "machine operators" than as "more in the role of mediators of experience, as decision-makers and coordinators... [that is,] the variety of job content for the individual employee will increase" (Kagermann 2014, p. 608; e.g. also Bauernhansel 2014; Wissenschaftlicher Beirat 2014).

This perspective on the development of work corresponds to a model of work organization at the enterprise level characterized by a high degree of structural openness, a very limited division of labor and high flexibility. For, as labor sociological findings show, this is the organizational precondition for the qualifications and experience of employees to be brought to bear in the ongoing system and, above all, for them to be able to cope at any time with unanticipated incidents and particular situations through competent and experience-tested action. In the debate over the digitization of work, one model of work organization is variously emphasized for its perspective on the evolution of change in work: holistic organization or, metaphorically, also swarm organization (Hirsch-Kreinsen 2014). This organizational model is characterized by a loose network of qualified and equally entitled employees. Simple and low-skill jobs are not to be found because they have been (or will be) largely replaced by automated processes. The central feature of this organizational model is that there are no defined tasks for individual employees. Rather, the work "collective" functions in a self-organized, highly flexible and situationally determined way, varying its behavior with the problems to be solved in and on the technological system. However a frame of action exists, predetermined by top-level management, prescribing the basic rules of action, strategic objectives, collective orientations and guiding policies, for an optimally trouble-free and smooth technological process (Neef and Burmeister 2005).

In other words, this model of work organization aims for the explicit use of informal social processes of communication and cooperation and the associated extra-functional skills and the accumulated specific process knowledge of employees. To follow Böhle (1992), this organization model is based on the necessary interplay of general social capabilities such as communication and methodological skills with practical work-process knowledge specific to the given manufacturing process.

\subsubsection{Polarization of qualifications}

The other pole is represented by the notion of the "polarization" of job activities and skills. Its central developmental mechanism is an increasing erosion and replacement of medium-level skills. Accompanying this is a growing share of demanding, high-qualification activities on the one hand, and the preservation and partly the expansion of easier but not routinized and therefore not automatable activities on the other. This thesis is particularly prominently represented by the author, as well as Dorn (2013), Collins (2014) and Brynjolfsson and McAfee (2014) who, especially in macrostructural perspective point to the development of the US labor market, but also variously to transformations in the EU labor market (e.g. Goos et al. 2009; Bowles 2014). On this view, generally in the last two decades the proportions of demanding jobs in managerial, technical and professional occupations, but also those of less demanding activities in the service and industrial sector, have increased, while the shares of medium-skill job areas such as sales, administration and industrial production have stagnated or decreased.

The reason for this development is that not only simple, routinized activities, but especially also many activities on intermediate skill levels can be automated and thus substituted. The prerequisite however for this is that these should be activities of a well-structured and rule-oriented character and can therefore be suitably algorithmized. Specifically, these have been usually quite demanding types of production work such as machine, e.g. automotive installation and system monitoring, as well as many routine administrative and service activities on medium skill levels (Autor 2010; Marin 2014; for an overview see Autor 2013). As already 
described in the context of the consequences of the new technologies for the labor-market (see Part 3.1), through the new technologies also relatively routinized work in segments of mid-range complexity and income is also becoming increasingly automated. Complex activities in high-wage areas such as management, consulting or financial services, and low-wage jobs such as simple manipulation and monitoring activities, nurses and geriatric nurses, however, enjoy high demand (Marin 2014). Goos and Manning characterize this trend as the emergence of "Lousy and Lovely Jobs" (Goos and Manning 2007).

This macrostructural justification for a polarizing trend is mirrored by research that focusses on the workplace level, such as a broad German study on the development of skilled-worker jobs in industrial companies, whose authors fear a progressive "de-skilling and part-substitution" of intermediate skill levels as a result of information technology automation in those areas. They can speak at best only of the uncertain destiny of such "residual categories" of skilled labor which are activities that cannot be automated or would cause a disproportionate expense in order to be automated (TA 2007; Kinkel et al. 2008; Düll 2013). Similarly argue Windelband et al. (2011) in their study of work in the context of intelligence-networked logistics systems, which creates at the enterprise level the tendency towards a differentiated structure of activities between sophisticated, high-skill jobs on the one hand, and some remaining but devalued specialist tasks and non-automated simple activities on the other hand. This deskilling is also referred to as "Digital Taylorism" since the digital technologies allow an optimization of Taylor's principles of work simplification and work control especially for complex tasks (The Economist 2015, p. 63). However, also new jobs for low-skilled workers may arise thereby. It can therefore be assumed that low-skilled employees will be not, as the Upgrading thesis assumed, largely substituted by digital technologies. ${ }^{3}$

This perspective of polarization corresponds at the enterprise level to a work-organizational design model with a strongly exhibited division of labor. On the one hand it is characterized by a low number of simple activities with little or no room for maneuver, such as standardized monitoring and control tasks. On the other hand, an extended or even newly created group of highly qualified experts and technical specialists emerge whose skill level is well above the previous skilled-worker level. These workers are responsible not only for dispositive issues such as coping with disturbances, but they also take on various tasks of production management. This model of work organization corresponds largely to currently prevailing forms of work in many high-tech companies, which can be characterized

\footnotetext{
${ }^{3}$ Concerning the contradictory consequences of digitization for lowskilled work see Hirsch-Kreinsen (2016).
}

as a contradictory combination of the design principles of decentralization and task-area broadening on the one hand, and of structuring and standardization on the other hand (e.g. Kinkel et al. 2008). In this way companies avoid highrisk or uncertain organizational innovations by following this already established path of work organization design. This model can thus be called in abbreviated form polarized organization.

\subsubsection{Developmental alternatives}

To summarize, it can be said that some very divergent development perspectives for digitized work can be argued. Quite obviously it is not possible to speak of the "one best way" of task and organizational design. It should also be stressed that the outlined poles of the spectrum of possible trends and work organization models denote conceivably extreme cases in the future situation. Rather, it is to be assumed that, in dependence on specific application conditions, system functions and structural workplace conditions, diverging and intermediate patterns of work organization will attune themselves to one another and ultimately become the object of company decision-making processes.

However, in labor research, plausible reasons for the possible relevance of swarm organization can be given in the context of the adoption of digitized production systems: An effective system control by skilled workers can be assured with minimally regulated, informal and cooperative forms of work processes (Lee and Seppelt 2009; Cummings and Bruni 2009). Moreover, it is quite possible in the context of such a model of work organization to maintain control over real-time decision-making and communication processes (Spath et al. 2013, p. 115). In addition it is emphasized that complex systems change states "spontaneously" and have intransparent and unpredictable effects (Grote 2005) that require highly flexible workplace interventions that are as unplannable as they are uncontrollable. In addition, it is assumed that the lengthy introduction and start-up phases of Industry 4.0 systems are due to their complexity, in the course of which activities and work organization must show a high degree of flexibility and problem-solving skills, while still far from able to reach a definable (end-) state. Finally, the "lifecycle" of complex systems is referred to, which can always involve new system states that are difficult to control; both unexpected start-up problems, as well as current problems and unexpected disturbances in normal operation can subsequently only be overcome in the context of open and informally designed forms of work (BMWi 2013).

Finally, in this context, it should be asked what effects the information-technologically possible temporal and spatial separation of work functions from the real process, and above all the possibilities of their temporal and spatial flexibilization will have for the design of work and the dis- 
tribution of capabilities (Kinkel et al. 2008, p. 245). This option applies to the activities at the shop-floor level as well as those at higher hierarchical levels, because the boundaries of organizational structures are confused in this way; it is probably becoming more and more difficult to speak of well-defined models of work organization and company hierarchy, while work processes are taking on an increasingly informal and unstructured character. Communication and social interaction in the work process will perhaps then be mediated mainly or only through IT and other mediaapplications, and the above model of swarm organization will possibly predominate as the leading form of largely unbounded work. Thus new forms of cross-company distributed, Internet-based, and in tendency global labor relationships are conceivable, which have recently been discussed under the heading of "crowdwork" (e.g. Leimeister and Zogaj 2013; Benner 2014).

\section{Determining factors}

\subsection{Conceptual considerations}

Because apparently in the case of smart production systems there are very different developmental paths of production work, the question is understandable what determinants influence the development of organization, jobs and qualifications. The answer to this question, however, requires preliminary conceptual clarifications, because a large number of relevant studies and analyzes suggests a conception which assumes a more or less deterministic relationship between technological development and the consequences for work. According to this, there is currently taking place a "technology push" with ultimately clear and predictable social and economic trends toward change (e.g. Evangelista et al. 2014). By contrast, both innovation research as well as work-sociological technology studies have at their disposition a broad stock of conceptual and empirical research results that show instructively how the development, diffusion and implementation of new technologies proceeds anything but seamlessly and consistently, and that above all the social effects are scarcely derivable unambiguously. Thus evolutionary theory approaches to innovation research have long emphasized that innovations, though always purposeful and dynamic, are at the same time chronically risky in their course and uncertain in outcome. Decisive for each historical pattern of innovation and thereby the initiated structural changes that play out, are thereby, for one, the development and variation of technologically possible potential, and for another, its environmental selection in the light of application requirements and marketing opportunities for new technologies and their products (e.g. Fagerberg 2005). Similarly argues the sociology of work: Ever since the critical debate over "technological determinism" of the $1970 \mathrm{~s}$ and $80 \mathrm{~s}$, it has been thought that a relation exists between the implementation of certain technical systems and the consequences for work, which is influenced by many non-technical and social factors. By no means should it be assumed - just on the basis of the technology - that there is a clear and constant relationship between the two dimensions (Lutz 1987; for a summary: Pfeiffer 2013).

Overall therefore it can be maintained that an understanding of the relationship between the proliferation of digital technologies and their social consequences is never linear and deterministic. Rather, it is a matter of a complex and reciprocal relationship shaped by the influence of multiple economic, social and labor-political factors that ultimately determines in what way the given new technological application potentials will actually be put to work, and what outcomes for labor will emerge (Evangelista et al. 2014, p. 803). Moreover, as technology research in the sociology of work of recent decades has shown, it is often the form of the labor-organization's embeddedness in and the ultimate form of the new technologies that are the determining factors for their use. It has become clear particularly that technical and organizational design alternatives always exist that remain the domain of company and labor policy decision-making processes (Hirsch-Kreinsen et al. 1990; Brödner 1997).

The analysis and ultimately the organization of the process of digitization of work, i.e. the interaction of the new technology with the resulting personnel and organizational changes therefore requires a conceptual view of the overall context of the production, and the interdependencies that are at work within it. An analytical starting point for this is offered by the concept of the "sociotechnical system" which encompasses the interdependent relationship between the technological, organizational and human elements of an overall system of production (Trist and Bamforth 1951). Although this has not always been defined consistently in research, approximatively, and after Rice (1963), a sociotechnical system can be understood as a production unit consisting of interdependent technological, organizational and personnel subsystems. This means that, while the technological subsystem limits the design possibilities of the other two subsystems, these have independent labor-psychological, labor-policy and organizational features which in turn react with the functioning of the technological subsystem. This concept avoids asking only about the functioning of the processes of change in individual technical and non-technical elements, but instead it puts the overall interaction and combination of elements - hence the technosocial - into the focus of the analysis.

If one now asks what concrete determining factors are relevant to the system design and forms of work we find in the current literature thus far only few indications. How- 
ever, if one looks at the older literature on the introduction of computer-integrated manufacturing systems (SchultzWild et al. 1986; Hirsch-Kreinsen et al. 1990), two determining factors can be regarded as crucial for the design of the whole system und especially for the development of work: the technologically oriented automation concept followed by each of the user companies, and associated with that, the introduction processes of the new systems. Both factors will be discussed briefly in the following.

\subsection{Alternative automation concepts}

As to the determining factors in the development of work, a first answer is provided by a glance at the interdependence relations between the technical and non-technical elements of a sociotechnical system, in particular the design of the technical subsystem and the associated room for organization and work. Following the literature, one can speak of "alternative automation concepts". Here two fundamentally different system designs can be distinguished (e.g. Hollnager and Bye 2000; Kaber and Endsley 2004; Cummings and Bruni 2009; Lee and Seppelt 2009; Grote 2005):

One is a technology-centered automation concept. This conception takes the direction of a far-going replacement of work functions by automatic installations. The role of human intervention in the work has then only a compensatory character. The remaining tasks for workers are those that can be automated only with difficulty or not at all, and are generally surveillance tasks. Otherwise formulated, human action in the work has now a temporary function and the conceivable final state of such a system conception is its complete automation. Unquestionably, with this system concept there are progressively narrower limits on the place for human creativity in the work.

On the other hand, a complementary automation concept posits the development of a distribution of tasks between humans and machines which should make possible a satisfactory functional capability of the total system. This design requires a holistic or collaborative perspective on the human-machine interaction which identifies the specific strengths and weaknesses of both human labor and technical automation. For the development of work in this conception, a technological framework is established that can serve in different ways.

In the relevant social-science literature it is unanimously assumed that only a complementary system interpretation is sufficient for the optimal exploitation of the technological and economic potential of smart production systems, for it doesn't relegate human intervention in work systems to only a few fragmentary functional remains, as does the technology-centered automation concept. Instead, the complementary conception opens design possibilities for work that minimizes e.g. awareness and feedback problems of acting on complex installations, make possible informal and manipulative action and ongoing learning processes, and thereby permit a sufficient regulative capacity of the total system.

To follow Grote's formulation, with such an approach the specific strengths and weaknesses of humans and technology will not be regarded "....in the sense of an either-or, human or technology, ...but rather merged into a new quality of the total system by means of a thorough elaboration of the human-technology interaction." For this the three dimensions of the sociotechnical system concept are equally involved in the system development in order to make it able to deal with variations and disruptions (Grote 2005, p. 67). As essential formative criteria are mentioned for example (ibid.): the possibilities to monitor the technology, a motivation-oriented task structure, as well as an organizationally enabled self-regulation of activities.

\subsection{Implementation process}

In total, these considerations and findings indicate the great influence not only of the fundamental development and formative processes of the new production systems, but also of the actual implementation process of a new system at each end-user plant on the development of industriel work. The significance of the implementation process for the ultimate system design and model of production work realized is grounded above all in the fact that the new smart systems normally cannot be implemented at all as "turnkey solutions" or as it were, "plug-and-play-ready" in workplaces. And it is only seldom the case that an intelligent factory is built from the ground up on the "greenfield" as a total concept. Rather, most autonomous systems will probably be integrated first as "island solutions" within bigger production segments in existing technical-organizational structures of user companies. Therefore in the concrete introduction phase, under certain circumstances a long and drawn-out, costly and reciprocal process of coordination between the new system and the existing plant's conditions will be required.

Here attention is drawn particularly to the extremely costly harmonization of the new system with existing databases and systems (Spath et al. 2013, p. 123; also: Schuh and Stich 2013, p. 229). Overall therefore exhaustive introductory and startup phases in smart systems should be assumed, in the course of which production activities and the work organization will have to demonstrate high flexibility and problem-solution capabilities, and can hardly be expected to soon reach a definable end-state. Variously are mentioned also the "life-cycle" of such complex installations continuously new and difficult system conditions that permanently require ever-newer forms of work organization and personnel engagement (BMWI 2013). 
Whether and how these challenges are managed depends in turn on many additional company and managementstructural factors. Earlier studies on the introduction of computer-integrated systems thus point to the often overloaded factory resources of planning capacity, know-how and available financial leeway. The restrictive influence of a lack of resources is particularly evident when smaller and scarcely technology-intensive firms decide to adopt smart production systems. Furthermore the course of the implementation process may be affected by labor- and company-political issues. As relevant may also be considered the internal constellation of plant actors participating in the introduction, as for example in the way key promoters in management, or in project-group formation, commit themselves to decisionmaking processes. Which automation concept ensues in specific cases, and how the work organization comes to be structured, could be decisively influenced by which actors are especially influential.

\section{Conclusions}

To sum up, currently smart production systems may have only limited development prospects and it should be emphasized that the possibilities of realization have by far not been definitively recognized. This is because the industrial diffusion of these systems, with their structure-changing character, is confronted by technical, economic and social barriers that are hard to overcome. In other words, it must be assumed that the innovation of smart production systems has an exceptionally paradoxical character. ${ }^{4}$ Its structurechanging effects provoke simultaneously opposition, limitations and barriers to its realization. This can be due to the following factors:

- First, there are the above-mentioned problems of data migration and the integration of the new systems into the existing production structures and databases, the costs and complexities of which presently seem scarcely fathomable.

- Second, indications of acceptance problems of the new concept on the part of management and among industry practitioners cannot be overlooked. A substantial role plays here quite evidently a widespread skeptical attitude towards the automation and the efficiency promised by the smart systems, based on their long years of practical and contradictory experiences with automation. Beyond that, smart systems with their technological principles of decentralized, automated self-organization collides with widespread organizational concepts of standardization

\footnotetext{
${ }^{4}$ In innovation research an "innovation paradox" is referred to when a technological innovation carries within itself reasons for its failure (e.g. Andriopoulos and Lewis 2009).
}

and lean production, by which often sustainable efficiency gains and increases in the steerability potential of processes are realized. In this regard the concept contradicts in several ways the dominant guiding wisdom on how to structure an efficient factory. Besides, there is often reserve out of (very comprehensible) fears for the data security of the complex databases that must be elaborated in highly networked, intelligent production systems.

- Third, organizational inertia should be taken into account. This is probably the particular consequence of the necessary restructuring of company planning and control levels, and a changed distribution of duties between IT and production technology. For generally, IT competencies and duties should increase massively in importance and be merged with the other existing production-technical competencies. There is concern that, in particular, technical experts could use their existing influential position to slow down rapid change or even block it. Possibly such a defensive stance towards a loss of competence (or autonomy) could also be hardened by the fear of the surveillance potential of the digital systems.

It can be assumed therefore that in the industrial sector in total, in the medium term a rather differentiated landscape of the diffusion and application of smart production systems will be observed. Above all such enterprises will seize the opportunity of the new systems who, because of high flexibility requirements, are permanently under pressure to innovate and rationalize, and in the new systems see a chance to achieve sustainable productivity increases. Typical of these are technology-intensive, strong mid-scale firms who above all have the necessary qualified personnel and capabilities and have made famous the German industrial structure. Examples are medium-sized, technology intensive and highly innovative firms of the mechanical engineering and metal industries. Also the area of logistics, because of its standardized processes and rapid growth, should become in the mid-term a promising user of smart systems (cf. Spath et al. 2013; Hirsch-Kreinsen et al. 2015).

By contrast, rather reserved towards smart systems will be such enterprises who, as large-scale producers, have already progressed very far in highly automated production technologies and organization. For them, specific and newer automation logics of smart systems would probably endanger their achievement of high productivity and with that, their existing competitive advantage. Examples are flexible, large-scale producers in the automotive and electro-technical sectors. Presumably these systems will also scarcely interest the wide area of technologically lowintensity small and middle-size enterprises (SMEs) (cf. FAZ 2014). The reasons for this lie, for one thing, in the limited resources and capabilities of most SMEs, who therefore 
aren't usually willing to go for technological experiments with uncertain results. For another thing, many SMEs are in sectors that are traditionally successful producing relatively standardized goods at a modest level of automated technology. These enterprises, for example in nutrition products, the furniture industry or metal goods, are subjected to only low-flexibility demands, so that costly and risky automation measures for them will probably not even need to be seriously considered. These forms of low-qualification, straightforward industry jobs should therefore remain in the foreseeable future.

Overall however, hardly any definitive and sure assumptions about the future dispersion of smart production systems can be formulated. The arguments made here are therefore highly hypothetical. But with that a wide field of future social-science research on innovation and work is laid out which will concern itself with changes in the work of production in the context of the introduction of smart production systems. Such an agenda could take in analytically oriented basic research as well as projects in applied research, for example on technologically oriented development and application attempts. In any case however, the newness and complexity of this area only make still more obvious the need for an interdisciplinary approach between the technical and social sciences. Above all the burning question - and one in no way yet even approaching a definitive answer-is whether this economic and social development, as the German discussion surrounding Industry 4.0 would have it, is indeed the threshold of a " 4 th Industrial Revolution".

\section{Kurzfassung}

Im Beitrag werden erste Forschungsergebnisse über die Konsequenzen des Einsatzes digitaler Technologien für industrielle Arbeit zusammengefasst. Der Fokus richtet sich besonders auf die Entwicklung der deutschen Industrie, deren Entwicklung unter dem Label „Industrie 4.0“ seit längerem intensiv diskutiert wird. Ausgangsannahme ist, dass gegenwärtig ein weit reichender Technologieschub in der industriellen Produktion stattfindet. Es wird dabei davon ausgegangen, dass sich mit Industrie 4.0 weitereichend neue Produktivitäts- und Marktpotentiale für die industrielle Produktion verbinden. Insbesondere wir von grundlegenden Strukturveränderungen der Arbeitsprozesse ausgegangen. Wie sich Industriearbeit allerdings verändert, ist offen und Gegenstand intensiver Diskussionen. Auf der Basis der derzeit vorliegenden Literatur und der Forschungsergebnisse können auf diese Frage derzeit keine endgültigen Antworten gegeben werden. Der derzeitige Stand der Forschung lässt sich in den folgenden Punkten zusammenfasen:
1. Die Konsequenzen für Industriearbeit werden sowohl in quantitativer als auch qualitativer Hinsicht kontrovers diskutiert und die formulierten Thesen sind teilweise widersprüchlich. In Hinblick auf mögliche Arbeitsplatzverluste ist unstrittig, dass die Digitalisierung von Industriearbeit kurzfristig zu Freisetzungen führen wird. Umstritten ist derzeit aber, ob diese sich dauerhaft durchsetzen oder ob Freisetzungseffekte längerfristig durch neu entstehende Aufgaben und Arbeitsplätze kompensiert werden. Insgesamt allerdings ist zu befürchten, dass besonders einfache Tätigkeiten mit niedrigen Qualifikationsanforderungen in Zukunft zunehmend durch digitale Technologien substituiert werden.

Auch in Hinblick auf die Entwicklung von Tätigkeiten und Qualifikationen sind unterschiedliche Trends erkennbar:

- Auf der einen Seite finden sich Tendenzen des Upgrading von Tätigkeiten und Qualifikationen. Upgrading von Qualifikationen kann dabei als Folge der Automatisierung einfacher und gering qualifizierter Tätigkeiten und dem Erhalt und dem Ausbau qualifizierter Tätigkeiten. Darüber hinaus kann Upgrading aber auch als ein Prozess verstanden werden, der generell alle Beschäftigtengruppen erfasst.

- Auf der anderen Seite finden sich Tendenzen, die als Polarisierung von Tätigkeiten und Qualifikationen gefasst werden können. Der Kern der Polarisierungsthese ist, dass sich zunehmend eine Schere zwischen komplexen Tätigkeiten mit hohen Qualifikationsanforderungen einerseits und einfachen Tätigkeiten mit niedrigem Qualifikationsniveau andererseits öffnet und mittlere Qualifikationsgruppen dramatisch an Bedeutung verlieren. Daher werden einfache Tätigkeiten auch kaum durch Automatisierung verschwinden, vielmehr werden neue einfache Tätigkeiten mit niedrigen Qualifikationsanforderungen entstehen.

2. Ganz offensichtlich kann nicht von einem "one-bestway" der Aufgaben- und Organisationsgestaltung gesprochen werden kann. Es ist vielmehr davon auszugehen, dass sich je nach konkreten Anwendungsbedingungen, Systemfunktionen und betrieblichen Strukturbedingungen divergierende Muster der Arbeit einspielen. Grundsätzlich ist keineswegs von einem eindeutigen Zusammenhang zwischen Technikeinsatz und dem Wandel von Arbeit auszugehen. Vielmehr verfügt sozialwissenschaftliche Arbeitsforschung über einen breiten Fundus konzeptioneller und empirischer Forschungsergebnisse, die instruktiv zeigen, dass die Entwicklung, die Implementation neuer Technologien alles andere als bruchlos und widerspruchsfrei verlaufen und vor allem die sozialen Effekte kaum eindeutig ableitbar 
sind. Die Analyse des Zusammenspiels der neuen Technologie und der dadurch induzierten personellen und organisatorischen Veränderungen erfordert vielmehr den Blick auf das sozio-technische Gesamtsystem der Produktion und die hier wirksamen Zusammenhänge.

3. Einen besonderen Einfluss auf die Entwicklung und Gestaltung von Arbeit hat die konkrete Auslegung der digitalen Systeme. Einerseits kann von einem technologiezentrierten Automatisierungskonzept gesprochen werden. Diese Konzeption läuft auf eine weitreichende Substituierung von Arbeitsfunktionen durch die automatische Anlage hinaus. Anders formuliert, menschliches Arbeitshandeln hat in diesem Fall eine Lückenbüßerfunktion und der denkbare Endzustand einer solchen Systemauslegung ist die vollständige Automation. Andererseits kann von einem komplementären Automatisierungskonzept gesprochen werden. Dieses Gestaltungskonzept richtet sich darauf, eine Aufgabenteilung zwischen Mensch und Maschine zu entwerfen, die eine zufriedenstellende Funktionsfähigkeit des Gesamtsystems ermöglicht. Für die Gestaltung von Arbeit wird bei dieser Systemkonzeption ein technologischer Rahmen gesetzt, der in unterschiedlicher Weise genutzt werden kann.

Weiterhin verweisen die vorliegenden Befunde auf die Bedeutung des je konkreten Einführungsprozesses der neuen Systeme bei Anwenderbetrieben. Denn erst in dessen Verlauf ergibt sich in der Regel die konkrete Gestaltung des gesamten sozio-technischen Systems. Die Bedeutung des betrieblichen Einführungsprozesses für die letztendliche Systemauslegung und die sich durchsetzenden Muster von Produktionsarbeit begründet sich dabei vor allem in dem Umstand, dass die neuen Systeme im Rahmen langwieriger und aufwendiger Abstimmungsprozesse mit den bestehenden betrieblichen Bedingungen eingeführt werden müssen. In deren Verlauf müssen Tätigkeiten und Qualifikationen eine hohe Flexibilität aufweisen und können dabei auch mittelfristig kaum einen definierbaren (End-)Zustand erreichen.

4. Fragt man nach den Anwendungsperspektiven des Konzepts Industrie 4.0 und den damit verbundenen Konsequenzen für Industriearbeit, so muss betont werden, dass seine Realisationsmöglichkeiten bei Weitem nicht ausgelotet sind. Denn die industrielle Diffusion von Industrie 4.0-Systemen ist auf Grund ihres disruptiven und strukturverändernden Charakters mit nur schwer überwindbaren technischen, ökonomischen und sozialen Einführungsbarrieren konfrontiert. Angenommen werden kann daher, dass sich im industrieller Sektor Deutschlands mittelfristig eine differenzierte Landschaft von Industrie 4.0-Anwendungen durchsetzen wird. Aus diesen Gründen ist mit einem schnellen Wandel von Industriearbeit zunächst nicht $\mathrm{zu}$ rechnen. Vielmehr dürften sich längerfristig industriestrukturell bestehende Segmentationslinien zwischen unterschiedliche Qualifikationsniveaus, die mit unterschiedlichen Branchen und Betriebstypen korrelieren, vertiefen.

Open Access This article is distributed under the terms of the Creative Commons Attribution License which permits any use, distribution, and reproduction in any medium, provided the original author(s) and source are credited.

\section{References}

Aghion, P., Howitt, P.: Growth and Unemployment. Rev. Econ. Stud. 61(3), 477-494 (1994)

Altmann, N., Köhler, C., Meil, P. (eds.): Technology and Work in German Industry. Routledge, London (1992)

Andriopoulos, C., Lewis, M.W.: Exploitation-exploration tensions and organizational ambidexterity: managing paradoxes of innovation. Organ. Sci. 20(4), 696-717 (2009)

Autor, D.: The Polarization of Job Opportunities in the U.S. Labor Market. http://economics.mit.edu/files/5554 (2010). Accessed 13 July 2014

Autor, D.: The "task approach" to labor markets: an overview. J. Labour. Market. Res. 46(3), 185-199 (2013)

Autor, D., Dorn, D.: The Growth of Low-Skill Service Jobs and the Polarization of the US Labor Market. Amer. Econ. Rev. 103(5), 1553-1597 (2013)

Avant, R.: The third great Wave. In: The Economist, October 4th 2014, Special Report: (2014)

Bauer, W., Schlund, S., Ganschar, O.: Industrie 4.0-Volkswirtschaftliches Potential für Deutschland. FhG IAO, Stuttgart (2015)

Bauernhansel, T.: Die Vierte Industrielle Revolution-Der Weg in ein wertschaffendes Produktionsparadigma. In: Bauernhansel, T., ten Hompel, M., Vogel-Heuser, B. (eds.) Industrie 4.0 in Produktion, Automatisierung und Logistik, pp. 5-36. Springer Vieweg, Wiesbaden (2014)

BCG (The Boston Consulting Group): Industry 4.0-the Future and Growth in manufacturing Industries. https://www.bcgperspectives.com/Images/Industry 40 Future of Productivity April_2015_tcm80-185183.pdf (2015)

Benner, C.: Crowd Work-Zurück in die Zukunft. Bund-Verlag, Frankfurt a. M. (2014)

BMWI-Bundesministerium für Wirtschaft und Technologie: Mensch-Technik-Interaktion, Berlin (2013)

Böhle, F., Rose, H.: Technik und Erfahrung. Arbeit in hochautomatisierten Systemen. Campus, Frankfurt a. M. (1992)

Bonin, H., Gregory, T., Zierahn U: Übertragung der Studie von Fry/ Osborne: (2013) auf Deutschland. Forschungsbericht 455 Bundesministerium für Arbeit und Soziales, Berlin (2015)

Boos, D., Guenter, H., Grote, G., Kinder, K.: Controllable accountabilities: The Internet of Things and its challenges for organisations. Bevav. Inform. Tecnol. 32(5), 449-467 (2013)

Bowles, J.: The computerisation of European jobs - who will win and who will lose from the impact of new technology onto old areas of employment? www.bruegel.org/nc/blog/detail/article/1394the-computerisation-of-european-jobs/ (2014). Accessed 09 April 2015

Brödner, P.: Der überlistete Odysseus. Über das zerrütte Verhältnis von Menschen und Maschinen. Sigma, Berlin (1997) 
Broy, M.: Cyber-physical systems. Innovation durch softwareintensive eingebettete Systeme. Springer, Berlin (2010)

Brynjolfsson, E., McAfee, A.: The Second Machine Age: Work, Progress, and Prosperity in a Time of Brilliant Technologies. Norton, New York (2014)

Bullinger, H.-J., ten Hompel, M.: Internet der Dinge. Springer, Berlin (2007)

Collins, R.: Das Ende der Mittelschichtarbeit: Keine weiteren Auswege. In: Wallerstein, I., Collins, R., Mann, M., Derluguian, G., Calhoun, C. (eds.) Stirbt der Kapitalismus? Fünf Szenarien für das 21. Jahrhundert, pp. 49-88. Campus, Frankfurt a. M. (2014)

Cummings, M., Bruni, S.: Collaborative Human-Automation Decision Making. In: Nof, S. (ed.) Handbook of Automation, pp. 437-447. Springer-Verlag, Berlin (2009)

Dengler, K., Matthes, B.: Folgen der Digitalisierung für die Arbeitswelt Substituierbarkeitspotenziale von Berufen in Deutschland, IAB-Forschungsbericht. 11 (2015)

Düll, N.: Arbeitsmarkt 2030 Fachexpertisen und Szenarien. Trendanalyse und qualitative Vorausschau. http://www.wbv.de/openaccess/ artikel/6004384w (2013). Accessed 01 May 2014

Evangelista, R., Guerrieri, P., Meliciani, V.: The economic impact of digital technologies in Europe. Econ. Innovation. New. Tech. 23(8), 802-824 (2014)

Fagerberg, J.: Innovation: A Guide to the Literature. In: Fagerberg, J., Mowery, D., Nelson, R.R. (eds.) The Oxford Handbook of Innovation, pp. 1-27. Oxford University Press, Oxford (2005)

FAZ (Frankfurter Allgemeine Zeitung): Kleinbetriebe verschlafen die Digitalisierung, 9. Dez., p. 18 (2014)

Fleisch, E., Mattern, F.: Das Internet der Dinge. Ubiquitous Computing und RFID in der Praxis. Springer-Verlag, Berlin (2005)

Frey, C., Osborne, M.: The Future of Employment: How Susceptible are Jobs to Computerisation? Oxford Martin School (OMS) working paper. Oxford (2013)

Geisberger, E., Broy, M.: agendaCPS. Integrierte Forschungsagenda Cyber-Physical Systems. Springer-Verlag, Heidelberg (2012)

Goos, M., Manning, A.: Lousy and lovely jobs: The rising polarization of work in Britain. The Rev. Econ. Stat. 89(1), 118-133 (2007)

Goos, M., Manning, A., Salomons, A.: The Polarization of the European Labor Market. Am. Econ. Rev. 99(2), 58-63 (2009)

Grote, G.: Menschliche Kontrolle über technische Systeme-Ein irreführendes Postulat. In: Karrer, K., Gauss, B., Steffens, C. (eds.) Beiträge der Forschung zur Mensch-Maschine-Systemtechnik aus Forschung und Praxis, pp. 65-78. Symposium, Düsseldorf, (2005)

Harrington, J.: Computer Integrated Manufacturing. Industrial Press, New York (1973)

Hess, T.: Digitalisierung. http://www.enzyklopaedie-der-wirtschaftsinformatik.de/wi-enzyklopaedie/lexikon/technologien-methoden/Informatik-Grundlagen/digitalisierung/ (2015). Accessed 22 Feb 15

Hirsch-Kreinsen, H.: Wandel von Produktionsarbeit- "Industrie 4.0". WSI-Mitteilungen. 67(6), 421-429 (2014)

Hirsch-Kreinsen, H.: Wandel industrieller Einfacharbeit durch Digitalisierung: Strukturen, Perspektiven und Herausforderungen-eine Literaturstudie. Friedrich-Bert-Stiftung, Berlin (2016-forthcoming)

Hirsch-Kreinsen, H., Schultz-Wild, R., Köhler, C., von Behr, M.: Einstieg in die rechnerintegrierte Produktion: alternative Entwicklungspfade der Industriearbeit im Maschinenbau. Campus, Frankfurt a. M. (1990)

Hirsch-Kreinsen, H., Ittermann, P., Niehaus, J. (eds.): Digitalisierung von Industriearbeit. Hoffmann, Berlin (2015)

Hollnagel, E., Bye, A.: Principles for modelling function allocation. Int. J. Hum. Comput. Stud. 52(2), 253-265 (2000)
ING DiBa: Die Roboter kommen. Folgen der Automatisierung für den deutschen Arbeitsmarkt. https://www.ing-diba.de/imperia/md/ content/pw/content/ueber_uns/presse/pdf/ing_diba_economic research_die_roboter_kommen.pdf. (2015). Accessed 16 July 2015

Jasperneite, J.: Alter Wein in neuen Schläuchen? http://www. ciit-owl.de/uploads/media/410-10\%20gh\%20Jasperneite $\% 2$ 0CA\%202012-12_lowres1.pdf. (2012) Accessed 15 Jan 2015

Kaber, D., Endsley, M.: The effects of level of automation and adaptive automation on human performance, situation awareness and workload in a dynamic control task. Theor. Issues Ergonomics Sci. 5(2), 113-153 (2004)

Kagermann, H.: Chancen von Industrie 4.0 nutzen. In: Bauernhansl, Th, ten Hompel, M., Vogel-Heuser, B. (eds.) Industrie 4.0 in Produktion, Automatisierung und Logistik. Anwendung, Technologien, pp. 603-614. Migration. Springer-Verlag, Wiesbaden (2014)

Kersten, W., Koller, H., Lödding, H (eds.): Industrie 4.0. Wie intelligente Vernetzung und kognitive Systeme unsere Arbeit verändern. GITO-Verlag, Berlin (2014)

Keynes, J.M.: Essays in Persuasion, pp. 358-373. W.W.Norton \&. Co., New York (1963)

Kinkel, S., Friedewald, M., Hüsing, B., Lay, G., Lindner, R.: Arbeiten in der Zukunft: Strukturen und Trends der Industriearbeit. Sigma, Berlin (2008)

Lee, J.D., Seppelt, B.: Human Factors in Automation Design. In: Nof, S. (ed.) Handbook of Automation, pp. 417-436. Berlin (2009)

Leimeister, J.M., Zogaj, S.: Neue Arbeitsorganisation durch Crowdsourcing. Eine Literaturstudie. In: Arbeitspapier der Hans-Böckler-Stiftung, Reihe Arbeit und Soziales, Nr. 287 (Juli 2013), $1-112$ (2013)

Lutz, B.: Das Ende des Technikdeterminismus und die Folgen. In: Lutz, B. (ed.) Technik und Sozialer Wandel. Verhandlungen des 23. Deutschen Soziologentages, pp. 34-57. Campus verlag, Frankfurt a. M. (1987)

Marin, D.: Die brillanten Roboter kommen. In: FAZ, 21. November 2014, p. 16. (2014)

Neef, A., Burmeister, K.: Die Schwarm-Organisation-Ein neues Paradigma für das e-Unternehmen der Zukunft. In: Kuhlin, B., Thielmann, H. (eds.) Real-Time Enterprise in der Praxis, pp. 563-572. Springer Berlin, Berlin (2005)

Pfeiffer, S.: Arbeit und Technik. In: Hirsch-Kreinsen, H., Minssen, H. (eds.) Lexikon der Arbeits- und Industriesoziologie, pp. 48-53. Sigma, Berlin (2013)

Pfeiffer, S., Suphan, A.: Industrie 4.0 - das Gestaltungspotenzial der Beschäftigten anerkennen und nutzen. In: Hirsch-Kreinsen, $\mathrm{H}$. et al. (eds.) Digitalisierung industrieller Arbeit, pp. 205-230. Nomos, Berlin (2015)

Reinhart, G., Engelhardt, P., Geiger, F., Philipp, T., Wahlster, W., Zühlke, D., Schlick, J., Becker, T., Löckelt, M., Pirvu, B., Stephan, P., Hodek, S., Scholz-Reiter, B., Thoben, K., Gorldt, C., Hribernik, K., Lappe, D., Veigt, M.: Cyber-Physische Produktionssysteme. Produktivitäts- und Flexibilitätssteigerung durch die Vernetzung intelligenter Systeme in der Fabrik. wt-online. 103(2), 84-89 (2013)

Rice, A.: The enterprise and its environment. Tavistock publications, London (1963)

Rifkin, J.: The Third Industrial Revolution. How Lateral Power is Transforming Energy, the Economy, and the World. Palgrave Macmillan, Basingstoke (2011)

Scheer, A.W.: CIM (Computer Integrated Manufacturing)—Der computergesteuerte Industriebetrieb. Springer, Saarbrücken (1987)

Schuh, G., Stich, V. (eds.): Produktion am Standort Deutschland. Ergebnisse der Untersuchung 2013. Aachen (2013) 
Schultz-Wild, R., Asendorf, I., Behr, M. von, Köhler, C., Lutz, B., Nuber, C.: Flexible Fertigung und Industriearbeit. Campus, Frankfurt a. M. (1986)

Sendler, U. (ed.): Industrie 4.0. Springer, Berlin (2013)

Spath, D., Ganschar, O., Gerlach, S., Hämmerle, M., Krause, T., Schlund, S.: Produktionsarbeit der Zukunft-Industrie 4.0. Fraunhofer Verlag, Stuttgart (2013)

TA-Technikfolgenabschätzung: Zukunftsreport: Arbeiten in der Zukunft-Strukturen und Trends der Industriearbeit. Bericht des Ausschusses für Bildung, Forschung und Technikfolgenabschätzung (18. Ausschuss) gemäß $§ 56$ a der Geschäftsordnung. Deutscher Bundestag, Drucksache 16/7959: (2007)

The Economist 2015: Digital Taylorism. Sept 12th, 63 (2015)

Trist, E., Bamforth, K.: Some social and psychological consequences of the long wall method of coal-getting. Hum. Relat. 4(1), 3-38 (1951)

Westkämper, E.: Digital enterprise technology: digital manufacturing in the global era. Fraunhofer Publica, New York (2007)

Windelband, L., et al.: Zukünftige Qualifikationsanforderungen durch das "Internet der Dinge" in der Logistik. In: FreQueNz (eds.) Zukünftige Qualifikationserfordernisse durch das Internet der Dinge in der Logistik, Zusammenfassung der Studienergebnisse, pp. 5-9. Bertelsmann Verlag, Berlin (2011)

Wissenschaftlicher Beirat: Neue Chancen für unsere Produktion. 17 Thesen des Wissenschaftlichen Beirats der Plattform Industrie 4.0. Berlin (2014)

Wolter, M.I., Mönnig, A., Hummel, M., Schneemann, C., Weber, E., Zika, G., Helmrich, R., Maier, T., Neuber-Pohl, C.: Industrie 4.0 und die Folgen für Arbeitsmarkt und Wirtschaft. Szenario-Rechnungen im Rahmen der BIBB-IAB-Qualifikations- und Berufsfeldprojektionen. IAB-Forschungsbericht. 8 (2015)
Zammuto, R.F., Griffith, T.L., Majchrzak, A., Dougherty, D.J., Faraj, S.: Information Technology and the Changing Fabric of Organization. Organ. Sci. 18(5):749-762 (2007)

Zuboff, S.: In the age of the smart machine. The future of work and power. Basic Books, New York (1988)

Zuboff, S.: Creating value in the age of distributed capitalism. McKinsey Quarterly. http:/glennas.files.wordpress.com/2010/12/ creating-value-in-the-age-of-distributed-capitalism-shoshanazuboff-september-2010.pdf (2010). Accessed 20 Dec 2013

Hartmut Hirsch-Kreinsen, Prof. Dr. rer.pol., Dipl.Wirtsch.Ing. (Business Administration and Engineering) Professor at TU Dortmund University, Chair of Economic and Industrial Sociology 1997-2015; since April 2015 Research Professor at TU Dortmund University; 1980-1997 Research Associate at the TH Darmstadt University and the Institute for Social Research Munich (ISF München). A main research area is currently the increasing digitalization of production (in Germany discussed as "Industry 4.0") and its consequences for skills, working conditions and labor markets. He is visiting professor at several foreign universities and member of national and international advisory councils in the field of innovation policy, e.g. member of the Scientific Advisory Board of the German Platform "Industry 4.0". 